\title{
Driving growth performance shaped by environmental uncertainty and integrative strategy: The supply chain analysis of business transformation in ICT companies
}

\author{
Librita Arifiani $^{\mathrm{a}^{*}}$, Harjanto Prabowo ${ }^{\mathrm{a}}$, Asnan Furinto ${ }^{\mathrm{a}}$ and Wibowo Kosasih ${ }^{\mathrm{a}}$
}

${ }^{a}$ Bina Nusantara University, Jakarta, Indonesia

\begin{tabular}{l}
\hline C H R O N I C L E \\
\hline Article history: \\
Received April 7, 2021 \\
Received in revised format May \\
18,2021 \\
Accepted June 292021 \\
Available online \\
June 292021 \\
\hline Keywords: \\
Environmental uncertainty \\
Integrative capability \\
Business model transformation \\
Firm performance
\end{tabular}

\section{Introduction}

The modern global economy is on the border of the new industrial revolution. The evolutionary process of developing civilization continues to change, mainly due to the transformation of innovative technologies in telecommunications, such as the internet and digitalization (Hootsuite, 2019). Revolution 4.0 is a change in the way of human life and working as fundamentally, where the advancement of technology can integrate into the digital life (Iskandar, 2020). Thus, digital transformation in the context of Industry 4.0 is very important in community preparation to transfer society 5.0 (super-smart society), which reaches a high level of convergence between virtual space and physical space (Keidanren, 2016). In the Industrial 4.0 Revolution, technology had a massive influence, especially with the creation of the Internet of Things (IoT) and penetration of OTT services, where all work and equipment could be linked and run through the internet, this provides an opportunity for ICT companies. ICTs are companies or entities that provide internet connection services and other related services. ICT's market segment portfolio is quite clear, namely individuals and companies (retail and corporate). According to him, on a micro-level, the key to an ICT's business success lies in how high the quality of the company's ability to converge to three main aspects, namely: computing, communication, and content (Mason, 2020; Plate \& Ismail, 2020). In Indonesia, the information and communication sector recorded growth of $9.41 \%$ or the third-highest below the growth of other service businesses (BPS, 2019. Thus, the telecommunication industry is a significant contributor to the distribution of economic development throughout Indonesia (Statistics, 2018). The growth of ICTs has been driven by increased use of the internet. APPJI, in collaboration with Polling Indonesia, conducted a Survey of Indonesian Internet User Behavior Penetration \& Profile 2018. The survey results revealed that internet penetration in Indonesia in 2018 reached 64.8\%. In 2017, out of a total population of 262 million people, $54.68 \%$ or 143.26 million people were internet users. The number increased so that in 2018 , $64.8 \%$ of the 264.16 million inhabitants of Indonesia, or around 171.17 million people, were internet users (Indonesia Central

* Corresponding author

E-mail address: larifiani.binus@gmail.com (L. Arifiani)

(C) 2021 Growing Science Ltd. All rights reserved.

doi: $10.5267 /$ j.uscm.2021.6.013 
Bureau of Statistics, 2020; Focus Utama Buletin APJII, 2017). Besides, Indonesia's 4th rank among the countries in the world (after China, India, USA) with the highest number of internet users, with $64.8 \%$ internet user penetration (171 Mio), thus, Indonesia has the opportunity to have a competitive advantage to be able to compete globally (InternetWorldStat, 2019; Statista, 2020), however Kearney (2016) and Pigliapoco and Bogliolo (2011), divided the Internet value chain into five segments, namely: content rights, online services, enabling technology services, connectivity (ICT) the critical stage, and user interfaces. However, despite the significant increase in data traffic, there is a Covid-19 impact on declines in business service (Wyman, 2020). Although operators got growth, the Telco industry requires a large investment, yet the revenue is low. Digital services, although it has grown, has not been able to replace the decreasing operator's revenue (Plate \& Ismail, 2020). However, growth data traffic must be considered not able to cover the pressure of the telecommunications industry in the past few years due to the presence of over the top (OTT) services. It was already miserable long before Covid-19 because it was eroded by OTT (Bisnis.com, 2020; Statista, 2020). OTT players are considering a latent hazard for operators because OTT does not require large investments but generates profits through operator networks or "dumb pipes," providing bandwidth (ATSI, 2015; Figueiredo, 2016). These conditions indicate a problem in the Firm Performance of ICT companies in Indonesia, the current model of the telecommunications organization will not survive because the disruption pressures telecommunications companies to become platform companies that offer various services from content to software (Alliedmarketresearch, 2019) (KPMG, 2020). In the opinion of (Hunger \& Hhelen, 2013), performance is the result of the activity.

Business model Transformation is very important to overcome the phenomena that are facing organizations engaged in the Information and Communication Technology industry. Because the technology sector is constantly changing, companies must promote technological improvement, find strategic markets, and develop innovative business models, and exploit and evaluate opportunities to compete in different fields that will distinguish them from competitors. BMT becomes a major component in the digital environment. Zott et al. (2011) state that business model innovation appears as an alternative to process and product innovation, where managers and entrepreneurs create additional value in a given time. Such as shifting processes from the old business model into a new business model, due to the old/traditional business models will not function optimally in the face of a high competition market (Arnold, Kiel, \& Voigt, 2017). Therefore, companies need to change existing business models and adopt new business model approaches with changing the paradigm (Burmeister, Luettgens, \& Piller, 2015; Dijkman, Sprenkels, Peeters, \& Janssen, 2015; Mikusz, Schafer, Taraba, \& Jud, 2017). Implementation of BMT requires the support of organizational capability (Teece, 2018), and according to (Jiang, 2016; Teece, 2007), in the perspective of dynamic capabilities (DC) shows that integrative capability is the key to dynamic capabilities. Without effective integrative capabilities, uncertainty can inhibit the possibility of new recombination and integration of resources between companies (Jiang, 2016; Hutomo \& Pudjiarti, 2020). This capability is an important and key factor conducive to the transformation of business models and the promotion of sustainable value creation (Foss \& Saebi, 2016; Battistella, De Toni, De Zan, \& Pessot, 2017). Integrative abilities play an important factor, such as being able to integrate new business models through existing organizational infrastructure and all business components (Deloitte \& Forbes Insight, 2018; Geissbauer, Schrauf, \& Vedsø, 2016; Hermann, Pentek, \& Otto, 2016). For companies to be able to catch up with new markets or adopt new technologies, IC is needed. In the current era of paradigm shift known as Industry 4.0, companies must improve their IC and facilitate the sharing of knowledge between product engineering and production to achieve competitive advantage (Synnes \& Welo, 2016). Wei Jiang, Mavondo, and Matanda (2015) found that integrative capability has a significant direct impact on a firm's performance (marketing effectiveness and financial performance) and also indirect impact via the creation of new operational capabilities. The environment plays a special strategic role in the case of technology companies (Covin \& Slevin, 1991; GarcíaSánchez, García-Morales, \& Martín-Rojas, 2018; Rivera-Rodríguez, Garcia-Merino, \& Santos-Alvarez, 2017). However, Buliga and Voigt (2016) and Golden et al. (2018) found that ET has a negative impact on performance and compound by internal organizational change. Therefore, (Rivera-Rodríguez et al., 2017) search for the impact of uncertainty on performance have been investigated in a series of empirical studies, most focused on private sector organizations. Most of these studies support the proposition that uncertainty has a negative effect on performance (e.g., Anderson \& Tushman (2001), Lin \& Germain (2003), and Power \& Reid (2005).

\section{Literature Review and Conceptual Framework}

From the perspective of dynamic capabilities (DC), determining integrative abilities is the key to dynamic capabilities. Without effective integrative capabilities, it can overcome the difficulties of combinations and resources between companies (Jiang, 2016; Teece, 2007) stated, integrative as a company's capabilities to strategically acquire, collaborate the sources that are reachable in commercial enterprise partnerships in order to obtain managerial visions. Previous study found that integrative capability has a significant direct impact on company performance (marketing effectiveness and financial performance) and indirect impacts through the creation of new operational capabilities. However, according to (Jiang, 2016; Yu, 2012) the ability of integration from the perspective of a company's growth, four stages can contribute to improving the ability to grow, namely the ability to scanning, the ability to collect, the ability to combine (organization) and the ability to innovating and modifying resources (Helfat \& Campo, 2016; Helfat \& Raubitschek, 2018) (Pang, Wang, Li, \& Duan, 2019). Wei Jiang, Mavondo, and Matanda (2015) argue the company's knowledge system has four dimensions, namely: the company's engineering system (equipment, software, tools) where the employee's knowledge and skills are embedded, the company's 
organizational system (routines, procedures, and incentives) that direct the creation and control of employees' knowledge, knowledge and skills (both specific or scientific), and values and norms related to knowledge and by directing the creation and control of knowledge. In this study, the integrative strategy was measured by the dimensions shown in Table 1 .

Table 1

Variable operational of integrative strategy

\begin{tabular}{|c|c|c|c|}
\hline Variable & Dimension & Indicators & Source Literature \\
\hline \multirow{12}{*}{$\begin{array}{l}\text { Integrative } \\
\text { strategy }\end{array}$} & \multirow[t]{4}{*}{ Resource Match } & Match our advantage with partners' resources & \multirow[t]{4}{*}{ Pang et al., 2019; Helfat \& Campo, 2016} \\
\hline & & Utilize partner advantage & \\
\hline & & Optimize resources with cooperation & \\
\hline & & Optimize resources in environment changes & \\
\hline & \multirow[t]{3}{*}{ Partner Selection } & Evaluate the potential of partners & \multirow[t]{3}{*}{ Pang et al., 2019; Jiang, 2016} \\
\hline & & Establish the cooperation network & \\
\hline & & Build a good partnership & \\
\hline & \multirow[t]{3}{*}{ Risk control } & Assess the risk of external innovation & \multirow[t]{3}{*}{ Pang et al., 2019} \\
\hline & & Separate the risk of external innovation & \\
\hline & & Balance the risk of external innovation & \\
\hline & \multirow[t]{2}{*}{ Opportunity Identification } & Change of technology & \multirow[t]{2}{*}{ Pang et al., 2019} \\
\hline & & Change of competition & \\
\hline
\end{tabular}

Some people suggest that the environment is a pattern of all conditions and external influences that affect the life and development of the business organization. The contemporary business environment has been marked by increasing intensity of competition and a fast pace of change in markets and customer expectations. An uncertainty environment is in a situation that changes continuously, substantially, uncertainly, and unpredictable (Maxwell, 2017). Therefore, Pratono and Mahmood (2014) measured ET by the dimensions of competitive uncertainty, market uncertainty, and technological uncertainty. Turula and Bajgoric (2018) state that ET as the extent to which events are diverse and unpredictable in the environment in a particular industry (Tsai \& Yang, 2014; Wong, Lee, \& Chang, 2017). García-Sánchez et al. (2018) found that the uncertainty and complexity of the environment in which an organization operates and its relationships with stakeholders require companies to engage in continuous updating, collaboration with various parties, and process innovations, products, and systems to maintain a competitive advantage. ET changed the direction of the relationship between entrepreneurial management and company performance. ET changes the positive impact of entrepreneurial management on company performance. ET they assessed by dimensions: market uncertainty, technological uncertainty, and competitive intensity. In this study, the ET strategy is measured by dimensions: market uncertainty, regulatory uncertainty, and competitive uncertainty (Pratono \& Mahmood, 2014) (Table 2).

Table 2

Variable operational of Environmental Uncertainty

\begin{tabular}{|c|c|c|c|}
\hline Variable & Dimension & Indicators & Source Literature \\
\hline \multirow{8}{*}{$\begin{array}{l}\text { Environmental } \\
\text { turbulence }\end{array}$} & \multirow[t]{3}{*}{ Market turbulence } & Unpredictable customer demand & Duncan, 1972; Clark, 1985; Jauch \& Kraft, 1986 \\
\hline & & Rapidly changes the marketing practices & \multirow[t]{2}{*}{ Anderson, 1985; Jaworsky \& Kohli, 1993} \\
\hline & & Rapidly changes the customer preferences & \\
\hline & \multirow[t]{2}{*}{ Regularity turbulence } & Difficulty to predict regularity changes & \multirow{2}{*}{$\begin{array}{l}\text { Volberda \& Van Bruggen, 1997; Wijen \& van } \\
\text { Tulder, } 2011\end{array}$} \\
\hline & & Uncertainty of the law and regulation & \\
\hline & \multirow[t]{3}{*}{ OTT Intensities } & The intensity of price wars & \multirow[t]{3}{*}{ Jaworsky \& Kohli, 1993} \\
\hline & & The intensity of new product on the market & \\
\hline & & $\begin{array}{l}\text { Easiness of the competitors to compete with the } \\
\text { products offered }\end{array}$ & \\
\hline
\end{tabular}

Definition of Environmental turbulence: The innovative ability of organizations to respond to the complexity, and predictability of change business to follow the change of customer preferences, and market demands

Business model transformation emerged as an alternative to process and product innovations, with which managers and entrepreneurs created added value in specific times (Zott, Amit, \& Massa, 2011). BMT is known as a very important booster for achieving a competitive advantage. BMT is a redefinition reconceptualize of: (a) content (with the addition of new activities, (b) structure (relating to different activities), and (c) compliance (governance) (changes to units responsible for conducting activities) ((Srivastava, 2013) (Johansson \& Abrahamsson, 2014; Kim \& Min, 2015) found that companies that add new business models can improve their performance. Business model transformation in this study has been assessed with dimensions: New Technology/equipment, New Partnership, New revenue models, and New cost structures (Table 3).

Wheelen et al. (2015) conclude the definition of performance is the result of an activity. Selection of measures is needed to assess performance based on the type of organizational aspect. Among these performances is measured by profitability, market share, cost reduction. Business firm performance is the output or result of the application of all activities related to business activities (Best, 2009). Firm Performance indicators are sales growth and profitability (Hubbard and Beamish, 2011). Hunger and Hhelen (2013) revealed several measures of company performance, namely: a). Basic measurements, consisting of 
traditional financial measurements: through ROI, earnings per share (EPS), operating cash flow, and Shareholder value: economic value added (EVA) and market value added (MVA). b) Balanced scorecard approach: which combines financial measures with operational measures on customer satisfaction, internal processes, company innovation, and development activities. The BSC covers four areas: financial, customers, internal business processes, and learning and innovation. In this study, Firm Performance has been assessed from the dimensions: tangible process and intangible process.

Table 3I

Variable, dimension, and construct of BMT and firm performance

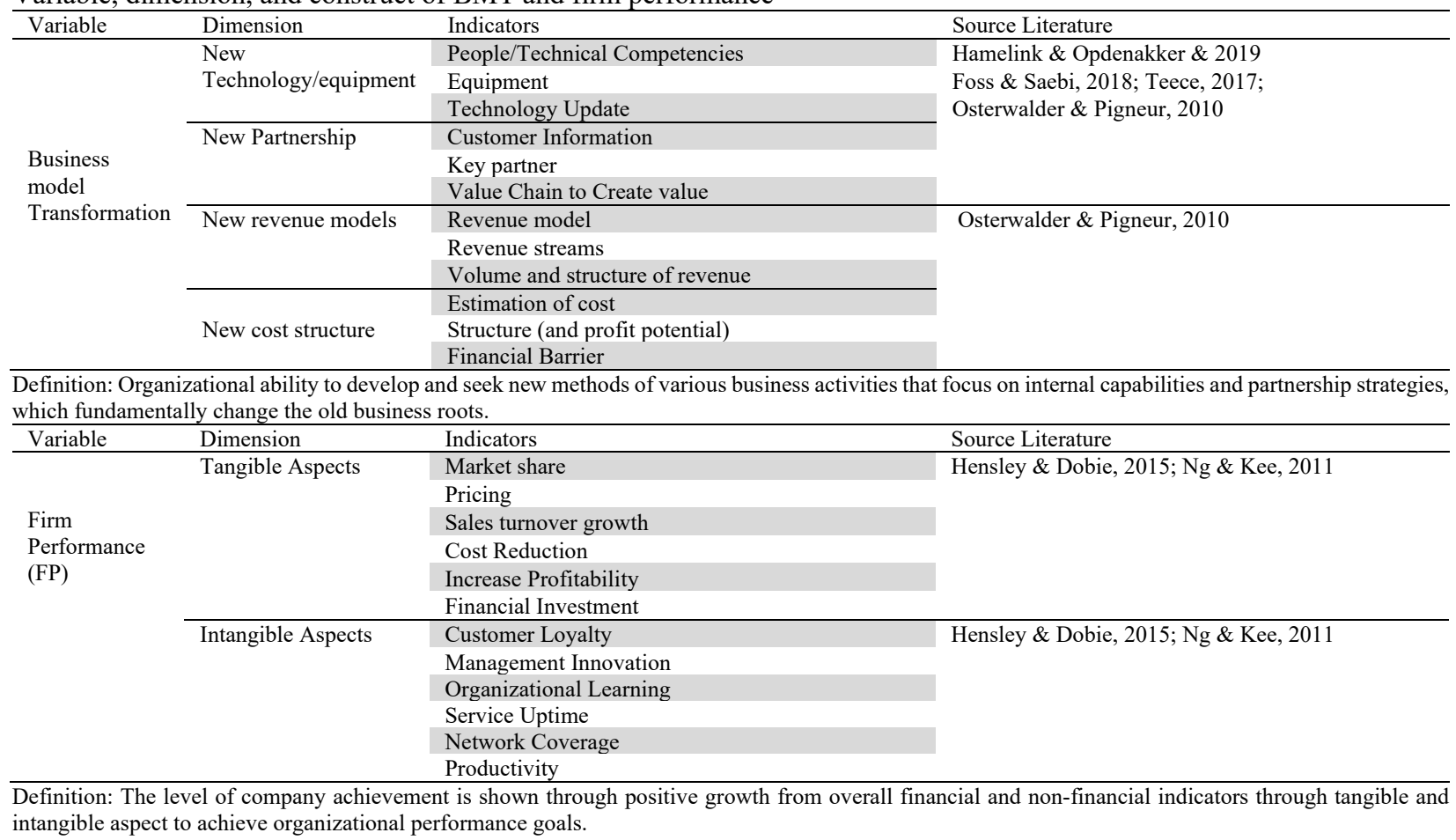

Based on the literature review of the above concept, the following hypotheses have arranged with the model being in Fig. 1:

H1. BMT affects firm performance.

H2. Integrative capability affects Firm performance.

H3. Integrative capability affects business model transformation.

$\mathbf{H}_{4}$. Environmental uncertainty strategy affects business model transformation.

H5. Environmental uncertainty strategy affects firm performance.

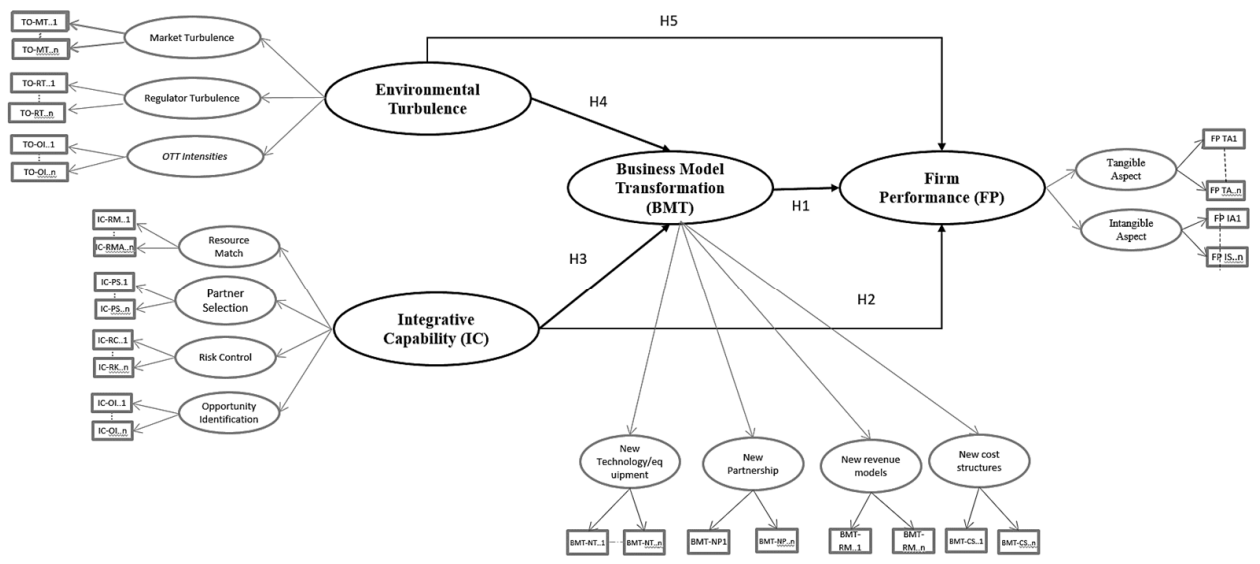

\section{Research Method}

Fig. 1. Research framework

The objectives of this study are to examine and reveal the relationship between variables through causality. Causal research, according to Aaker (2013, P. 66), "when it is necessary to show that one variable causes or determines the values of other 
variables, a causal research approach must be used." Unit of analysis is an ICT's company in Indonesia with the unit of observation being the company's management. Observations using time horizons are cross-section/one-shot, meaning that the information or data obtained is the result of research conducted at a certain time in 2020. The data used in this study are primary data obtained from questionnaires to management. ICT companies with a sample of 30 companies and 7 explanatory study with in-depth interview of top management ICT. Research data were collected via a questionnaire, phone call and distributed through several methods, including electronic form using Google form and printed format directly delivered to the respondents. The respondents were the executive management level of the firm, including the Board of Director, chief executive officer, chief technology officer, chief operating officer or Senior Manager of the selected companies who are believed to have sufficient knowledge on both company strategy, as well as the business process of the company. The unit analysis is the organization. Therefore, one valid questionnaire per organization represents one sample. The analytical approach and solution techniques that are used as analysis tools are Partial Least Square (PLS). This study used multivariable scales to measure the dimensions of constructs. These scales were derived from prior studies and reconceptualized in this study. All items have been assessed on five-point Likert scales ranging from 1 ("strongly disagree") to 5 ("strongly agree").

\section{Result and Discussion}

\subsection{Evaluation Model}

Before describing the verification analysis, the results of evaluation of the research model have been presented. Based on data processing, the degree of freedom obtained so that it has concluded that the model identified with the over-identified category. The path diagram of the estimated Model Research results is shown in Fig. 2 below:

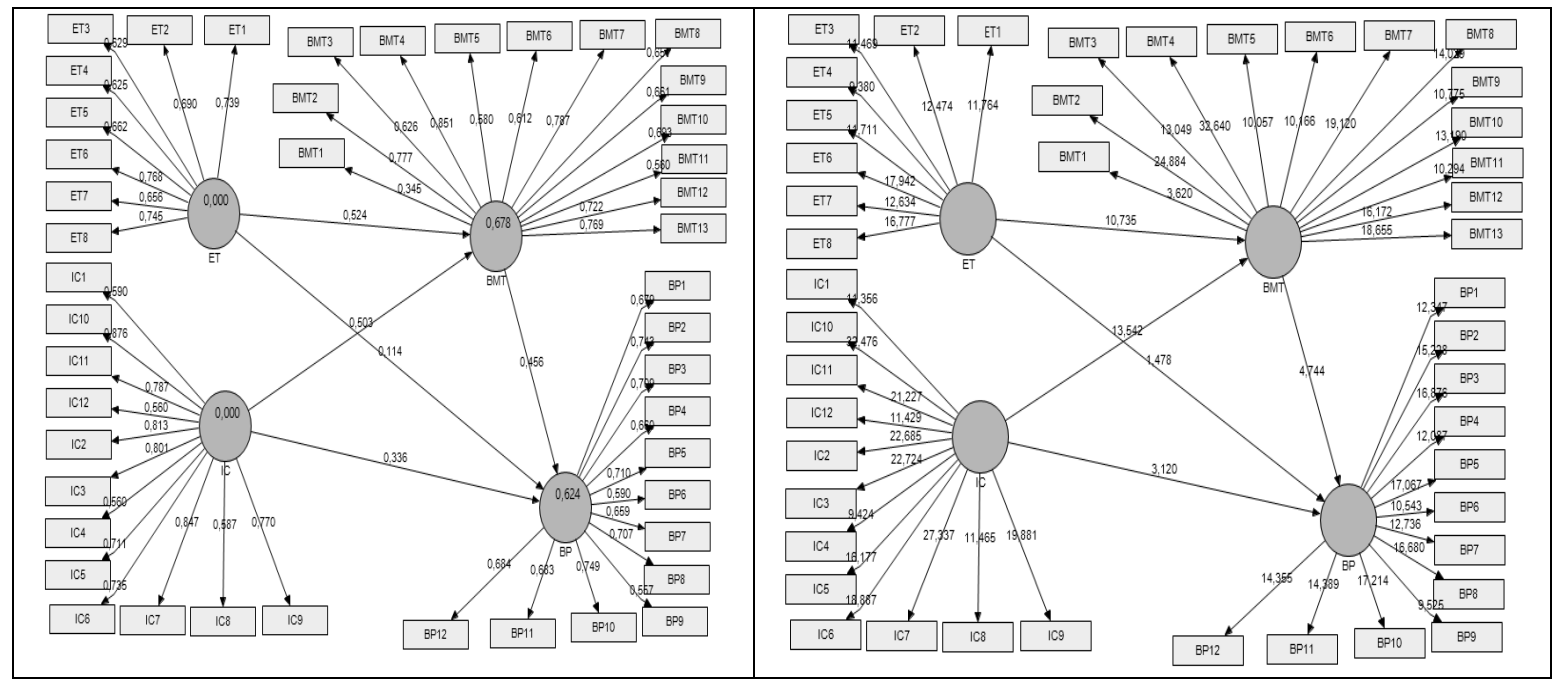

Fig. 2. Path Diagram

The structural analysis model (inner model) shows the relationship between latent variables. The inner model has been evaluated using R Square in the endogenous construct. The value of $\mathrm{R}$ Square is the coefficient of determination in the endogenous construct. According to Chin (1998), the R square valuesare 0.67 (strong), 0.33 (moderate) and 0.19 (weak). Prediction relevance (Q square) or known as Stone-Geisser. This test was conducted to determine the predictive capability with the blindfolding procedure. If the value obtained is 0.02 (small), 0.15 (medium) and 0.35 (large), and for endogenous constructs with reflective indicators. Here are the values of R-square and Q-Square in the moderate construct), and the value of Q square is in the big criteria, so it has concluded that the research model has been supported by empirical conditions or the fit model.

Table 4

Goodness-Of-Fit Model

\begin{tabular}{llll}
\hline Variable & R Square & $\begin{array}{l}\text { Cronbach's } \\
\text { Alpha }\end{array}$ & Q square \\
\hline Business model transformation & 0.678 & 0.896 & 0.348 \\
\hline Firm performance & 0.624 & 0.895 & 0.362 \\
\hline Environment uncertainty & & 0.845 & 0.309 \\
\hline Integrative capability & & 0.918 & 0.437 \\
\hline
\end{tabular}


Table 4 provides the $\mathrm{R}^{2}$ value on Firm Performance and Business Model Transformation as an endogenous variable within the criteria of more than 0.6 (strong) with a $Q$ square value $>0.15$ and 0.35 (large), so the proposed model is considered good and accepted as a model.

\subsection{Evaluation of Measurement Model}

Evaluation of latent variables is used to test the validity and reliability of each indicator from each dimension that forms the latent variables. Based on the weight of the factors (standardized loading) in the picture above, obtained the $t$ value of each indicator on the latent variables as presented in Table 5.

Table 5

Measurement Model

\begin{tabular}{|c|c|c|c|c|c|}
\hline \multirow[t]{2}{*}{ Variable } & \multicolumn{3}{|c|}{ Validity } & \multicolumn{2}{|l|}{ Reliability } \\
\hline & Indicator & Standardize loading & $\mathrm{t}$-value & Composite reliability & AVE \\
\hline \multirow{12}{*}{ Firm Performance } & $\mathrm{BP} 1 \leftarrow \mathrm{BP}$ & 0.679 & 12.347 & \multirow{12}{*}{0.911} & \multirow{12}{*}{0.562} \\
\hline & $\mathrm{BP} 2 \leftarrow \mathrm{BP}$ & 0.743 & 15.228 & & \\
\hline & $\mathrm{BP} 3 \leftarrow \mathrm{BP}$ & 0.709 & 16.876 & & \\
\hline & $\mathrm{BP} 4 \leftarrow \mathrm{BP}$ & 0.66 & 12.087 & & \\
\hline & $\mathrm{BP} 5 \leftarrow \mathrm{BP}$ & 0.71 & 17.067 & & \\
\hline & $\mathrm{BP} 6 \leftarrow \mathrm{BP}$ & 0.59 & 10.543 & & \\
\hline & $\mathrm{BP} 7 \leftarrow \mathrm{BP}$ & 0.659 & 12.736 & & \\
\hline & $\mathrm{BP} 8 \leftarrow \mathrm{BP}$ & 0.707 & 16.68 & & \\
\hline & $\mathrm{BP} 9 \leftarrow \mathrm{BP}$ & 0.557 & 9.525 & & \\
\hline & $\mathrm{BP} 10 \leftarrow \mathrm{BP}$ & 0.749 & 17.214 & & \\
\hline & $\mathrm{BP} 11 \leftarrow \mathrm{BP}$ & 0.683 & 14.389 & & \\
\hline & $\mathrm{BP} 12 \leftarrow \mathrm{BP}$ & 0.684 & 14.355 & & \\
\hline \multirow{13}{*}{$\begin{array}{l}\text { Business Model } \\
\text { Transformation }\end{array}$} & BMT1 $\leftarrow$ BMT & 0.345 & 3.62 & \multirow{13}{*}{0.913} & \multirow{13}{*}{0.557} \\
\hline & BMT2 $\leftarrow$ BMT & 0.777 & 24.884 & & \\
\hline & BMT $3 \leftarrow$ BMT & 0.626 & 13.049 & & \\
\hline & BMT4 $\leftarrow$ BMT & 0.851 & 32.64 & & \\
\hline & BMT5 $\leftarrow$ BMT & 0.58 & 10.057 & & \\
\hline & BMT6 $\leftarrow$ BMT & 0.612 & 10.166 & & \\
\hline & BMT7 $\leftarrow$ BMT & 0.787 & 19.12 & & \\
\hline & BMT8 $\leftarrow$ BMT & 0.651 & 14.029 & & \\
\hline & BMT9 $\leftarrow$ BMT & 0.661 & 10.775 & & \\
\hline & $\mathrm{BMT} 10 \leftarrow \mathrm{BMT}$ & 0.693 & 13.19 & & \\
\hline & $\mathrm{BMT} 11 \leftarrow \mathrm{BMT}$ & 0.560 & 10.294 & & \\
\hline & $\mathrm{BMT} 12 \leftarrow \mathrm{BMT}$ & 0.722 & 16.172 & & \\
\hline & $\mathrm{BMT} 13 \leftarrow \mathrm{BMT}$ & 0.769 & 18.655 & & \\
\hline \multirow{8}{*}{$\begin{array}{l}\text { Environment } \\
\text { Turbulence }\end{array}$} & ET1 $\leftarrow$ ET & 0.739 & 11.764 & \multirow{8}{*}{0.879} & \multirow{8}{*}{0.578} \\
\hline & $\mathrm{ET} 2 \leftarrow \mathrm{ET}$ & 0.69 & 12.474 & & \\
\hline & ET3 $\leftarrow$ ET & 0.629 & 11.469 & & \\
\hline & $\mathrm{ET} 4 \leftarrow \mathrm{ET}$ & 0.625 & 9.38 & & \\
\hline & ET5 $\leftarrow$ ET & 0.662 & 11.711 & & \\
\hline & ET $6 \leftarrow$ ET & 0.768 & 17.942 & & \\
\hline & ET7 $\leftarrow$ ET & 0.745 & 12.634 & & \\
\hline & $\mathrm{ET} 8 \leftarrow \mathrm{ET}$ & 0.59 & 16.777 & & \\
\hline \multirow{12}{*}{$\begin{array}{l}\text { Integrative } \\
\text { Capabilities }\end{array}$} & $\mathrm{IC} 1 \leftarrow \mathrm{IC}$ & 0.59 & 11.356 & \multirow{12}{*}{0.913} & \multirow{12}{*}{0.557} \\
\hline & $\mathrm{IC} 2 \leftarrow \mathrm{IC}$ & 0.813 & 22.685 & & \\
\hline & $\mathrm{IC} 3 \leftarrow \mathrm{IC}$ & 0.801 & 22.724 & & \\
\hline & $\mathrm{IC} 4 \leftarrow \mathrm{IC}$ & 0.56 & 9.424 & & \\
\hline & IC $5 \leftarrow$ IC & 0.711 & 16.177 & & \\
\hline & $\mathrm{IC} 6 \leftarrow \mathrm{IC}$ & 0.735 & 18.887 & & \\
\hline & $\mathrm{IC} 7 \leftarrow \mathrm{IC}$ & 0.847 & 27.337 & & \\
\hline & $\mathrm{IC} 8 \leftarrow \mathrm{IC}$ & 0.587 & 11.465 & & \\
\hline & IC9 $\leftarrow$ IC & 0.77 & 19.881 & & \\
\hline & $\mathrm{IC} 10 \leftarrow \mathrm{IC}$ & 0.876 & 32.476 & & \\
\hline & $\mathrm{IC} 11 \leftarrow \mathrm{IC}$ & 0.787 & 21.227 & & \\
\hline & $\mathrm{IC} 12 \leftarrow \mathrm{IC}$ & 0.56 & 11.429 & & \\
\hline
\end{tabular}

Table 5 shows variables with valid indicators with values Standardize loading $>0.50$ or $\mathrm{t}$ value $>2.01$ ( $\mathrm{t}$ table at $\alpha=0.05$ ). Reliability shows that the indicators have a high degree of conformity to form the latent variables with acceptable values (CR $>0.5$ ). AVE $>0.5$, which shows, on average more than $50 \%$ of the information contained in each indicator is reflected through their respective dimensions that can reflect all variables.

\subsection{Hypothesis Testing}

The results showed that $\mathrm{R}^{2}$ can be explained as the integrated capability, and environment uncertainty influences BMT of 0.678 or $67.8 \%$, where the Environment Uncertainty Strate has significant and greater influence $(\mathrm{R} 2=0.350)$. Integrated capability and environment uncertainty and BMT influence Firm Performance by 0.624 or $62.4 \%$ where only BMT has significant and greater influence $\left(\mathrm{R}^{2}=0.208\right)$ while Environment Uncertainty do not have a significant effect on Firm Performance $(\mathrm{t}$ value $<2.01)$. The results of hypothesis testing indicate that hypothesis 1 has been accepted, meaning that 
environmental uncertainty influences business model transformation. Hypothesis 1 has been accepted, meaning that BMT influences firm performance. Hypothesis 2 has been accepted, meaning that the IC strategy affects firm performance. Hypothesis 3 accepted, meaning that IC affects business model transformation. Hypothesis 4 accepted, meaning that the environmental uncertainty strategy affects BMT, However, hypothesis 5 rejected, meaning that the environmental uncertainty strategy does not affect firm performance.

Table 6

Hypothesis Test

\begin{tabular}{llllll}
\hline Hypothesis & $\begin{array}{l}\text { Estimate } \\
\text { Coeff. }\end{array}$ & $\begin{array}{l}\text { Standard } \\
\text { Error }\end{array}$ & $\begin{array}{l}\mathbf{t} \\
\text { values }\end{array}$ & $\mathbf{R}^{\mathbf{2}}$ & Conclusion \\
\hline BMT $\rightarrow$ FP & $0.456^{*}$ & 0.096 & 4.744 & 0.208 & Accepted \\
IC $\rightarrow$ FP & $0.336^{*}$ & 0.108 & 3.120 & 0.124 & Accepted \\
IC $\rightarrow$ BMT & $0.503^{*}$ & 0.037 & 13.542 & 0.328 & Accepted \\
ET $\rightarrow$ BMT & $0.524^{*}$ & 0.049 & 10.735 & 0.350 & Accepted \\
ET $\rightarrow$ FP & 0.114 & 0.077 & 1.478 & 0.024 & Rejected \\
\hline
\end{tabular}

*Significant at $\alpha=0.05$

The results show that the BMT predominantly influences the business performance of internet service provider companies. The BMT is predominantly built by the environmental uncertainty strategy rather than by IC. Thus, companies need to improve their ability and creativity to anticipate and adapt to any uncertainty that can occur unexpectedly and are very dynamic. This study estimates that ET can affect the growth of the company's performance through other mediating factors that need to be examined more deeply in the future study. The implications for the management of ICT service companies, contribute directly to businesses and entrepreneurs can formulate strategies to maintain and develop their business through opportunities of implementing business transformation models that can be considered a basic model in designing new business models and developing company capabilities to get company performance.

\section{Conclusion}

The results have shown that: the IC has influences on business model transformation, environmental uncertainty strategy has influences on business model transformation, environmental uncertainty strategy does not affect firm Firm Performance and business model transformation influences firm performance. The business model transformation predominantly influences the Firm Performance of ICT service companies. The business model transformation is predominantly built by the environmental uncertainty strategy when compared to integrative capability. The output of this study has implications for the management of ICT service companies that improving Firm Performance needs to be supported by the development of business model transformation. The development of business model transformation needs to be supported by an appropriate ET strategy and the development of integrative capability. The findings broaden the knowledge of the transformation model by embracing the internal (integrative capability-IC) and external (environmental uncertainty) perspectives. This study also re-conceptualizes the uncertainty dimension of competitors by adding a new indicator. OTT intensities (over the Top) players are a phenomenon in Telco and tested it empirically. Finally, these results highlight that optimal BMT needs to be framed by strategic ET to create a higher value for the transformation process. ET alone is not enough, and organizations need an integrative strategy to achieve company performance. Moreover, the practical implication side of the findings is to help to open entrepreneurial insights about the importance of dynamic continuous innovation towards the digital era to enhance the environmental uncertainty capability and integrative capability by formulating strategies in developing a transformation model. The social implication is to provide public benefits from the microeconomic side of society and macroeconomics to the Telco's industry. Improve internet service technology education in the community and increase internet user penetration. As limitations/implications, with the research approach chosen, research results may not be generalizable. Hence, future research could further explore the proposed propositions through the framework of the resulting business model with large data surveys and to extend the research to other industries.

\section{References}

Kearney, A. T. (2016). Capturing the Power of Frugal Innovation. A.T. Kearney

Alliedmarketresearch. (2019). Indonesia Over-the-top Market Size, Share and Analysis Forecast 2026. Retrieved from https://www.alliedmarketresearch.com/indonesia-over-the-top-market

Arnold, C., Kiel, D., \& Voigt, K. I. (2017). Innovative business models for the industrial internet of things. BHM Berg-und Hüttenmännische Monatshefte, 162(9), 371-381.

ATSI. (2015). ATSI sarankan OTT asing tunduk pada aturan di Indonesia. https://www.indotelko.com/read/1579053479/atsiottasing.

Battistella, C., De Toni, A. F., De Zan, G., \& Pessot, E. (2017). Cultivating business model agility through focused capabilities: A multiple case study. Journal of Business Research, 73, 65-82.

Bisnis.com. (2020). Wabah Corona, Industri Telekomunikasi Minta Insentif. Retrieved June 22, 2020, from https:/teknologi.bisnis.com/read/20200324/101/1217660/wabah-corona-industri-telekomunikasi-minta-insentif 
Buliga, O., \& Voigt, K. (2016). Why do business model innovators require organizational resilience ? From Science to Society: Innovation and Value Creation, (July), 1-12.

Burmeister, C., Luettgens, D., \& Piller, F. T. (2015). Business Model Innovation for Industrie 4.0: Why the "Industrial Internet" Mandates a New Perspective on Innovation. Ssrn, (January).

Covin, J. G., \& Slevin, D. P. (1991). A Conceptual Model of Entrepreneurship as Firm Behavior. Entrepreneurship Theory and Practice, 16(1), 7-26.

Clark, K. B. (1985). The interaction of design hierarchies and market concepts in technological evolution. Research policy, 14(5), 235-251.

Deloitte, \& Forbes Insight. (2018). The Fourth Industrial Revolution is here-are you ready? Deloitte Insights.

Dijkman, R. M., Sprenkels, B., Peeters, T., \& Janssen, A. (2015). Business models for the Internet of Things. International Journal of Information Management, 35(6), 672-678.

Duncan, R. B. (1972). Characteristics of organizational environments and perceived environmental uncertainty. Administrative Science Quarterly, 17(3), 313-327.

Figueiredo, A. (2016). How IoT Will Impact The Telecom Industry. Retrieved July 22, 2018, from https://medium.com/@alexandrefigueiredo_59277/how-iot-will-impact-the-telecom-industry-e8d275b2d9d9

Focus Utama Buletin APJII. (2017). Mendorong Kemampuan dan bisnis ISP. Retrieved from https://apjii.or.id/downfile/file/buletinapjiiedisi15setember2017.pdf

Foss, N. J., \& Saebi, T. (2017). Fifteen years of research on business model innovation: How far have we come, and where should we go?. Journal of Management, 43(1), 200-227.

García-Sánchez, E., García-Morales, V. J., \& Martín-Rojas, R. (2018). Influence of technological assets on organizational performance through absorptive capacity, organizational innovation and internal labour flexibility. Sustainability (Switzerland), 10(3).

Geissbauer, R., Schrauf, S., \& Vedsø, J. (2016). A Strategist’s Guide to Industry 4.0. Strategic Management Review, 83(may 2016).

Golden, P. A., Doney, P. M., Johnson, D. M., \& Smith, J. R. (2018). The Dynamics of a Marketing Orientation in Transition Economies: A Study of Russian Firms. Journal of International Marketing, 3(2), 29-49.

Hamelink, M., \& Opdenakker, R. (2019). How business model innovation affects firm performance in the energy storage market. Renewable Energy, 131, 120-127.

Helfat, C., \& Campo, R. (2016). Integrative Capabilities, Vertical Integration , and Innovation Over Successive Technology Lifecycles. Organization Science, (February), 1-16.

Helfat, C. E., \& Raubitschek, R. S. (2018). Dynamic and integrative capabilities for pro fi ting from innovation in digital platform-based ecosystems. Research Policy, (April 2017), 1-9.

Hensley, R. L., \& Dobie, K. (2005). Assessing readiness for six sigma in a service setting. Managing Service Quality: An International Journal, 15(1).

Hermann, M., Pentek, T., \& Otto, B. (2016). Design Principles for Industrie 4.0 Scenarios. In 201649 th Hawaii International Conference on System Sciences (HICSS) (pp. 3928-3937).

Hootsuite. (2019). Indonesia Digital 2019: Internet -. Retrieved from https://websindo.com/indonesia-digital-2019-internet/

Hutomo, P., \& Pudjiarti, E. (2020). Supply chain assessment of the organizational learning and market uncertainty on corporate performance of small scale steel industry in Indonesia. Uncertain Supply Chain Management, 9(1), 39-48.

Hunger, D., \& Hhelen, T. (2013). Strategic Management Model Gathering Information Societal Environment: General forces. Retrieved from https://proeunthat.files.wordpress.com/2013/11/concepts-in-strategic-management-business-policy.pdf

Indonesia Central Bureau of Statistics. (2020). Pertumbuhan Ekonomi Indonesia Triwulan IV-2019. https://www.bps.go.id/pressrelease/2020/02/05/1755/ekonomi- indonesia-2019-tumbuh-5-02-persen.html.

InternetWorldStat. (2019). Internet Top 20 Countries - Internet Users 2020. https://www.internetworldstats.com/top20.htm.

Iskandar. (2020). Society 5.0. Retrieved June 23, 2020, from https://iskandarsiregar.com/society-5-0/

Jauch, L. R., \& Kraft, K. L. (1986). Strategic management of uncertainty. Academy of Management Review, 11(4), 777-790.

JAWORSKY, B., \& KOHLI, A. (1993). Success factors in product innovation: A selective review of the literature. Journal of Marketing, 57, 53-70.

Jiang, W. (2016). Integrative capability for successful partnering : a critical dynamic capability.

Jiang, W., Tinoziva Mavondo, F., \& Matanda, M. J. (2015). Integrative capability for successful partnering: a critical dynamic capability. Management Decision, 53(6): 1184-1202.

Johansson, M., \& Abrahamsson, J. (2014). Competing with the Use of Business Model Innovation--An Exploratory Case Study of the Journey of Born Global Firms. Journal of Business Models, 2(1), 33-55.

Keidanren. (2016). Toward realization of the new economy and society. Policy \& Action. Japan Business Federation.

Kim, S. K., \& Min, S. (2015). Business Model Innovation Performance: When Does Adding A New Business Model Benefit An Incumbent? Strategic Entrepreneurship Journal, 10(2008), 235-256.

KPMG. (2020). COVID-19 dan industri telekomunikasi. https://advisory.kpmg.us/blog/2020/covid-19-and-telecomindustry.html.

Mason, A. (2020). Telecoms operators will not be immune to impact of COVID-19. https:/www.analysysmason.com/research/content/comments/COVID-scenario-forecast-article-May2020-rddg0-rdmm0rdmb0-rdvs0-rdmy0-rddf0-rdme0-ren02-ren01-rdmz0-rdns0/

Maxwell, M. (2017). The Relationship Between External Turbulence and New Product Development Practices. ProQuest 
Dissertations and Theses, (132), 214.

Mikusz, M., Schafer, T., Taraba, T., \& Jud, C. (2017). Transforming the connected car into a business model innovation. Proceedings - 2017 IEEE 19th Conference on Business Informatics, CBI 2017, 1, 247-256.

Osterwalder, A., \& Pigneur, Y. (2010). Business model generation: a handbook for visionaries, game changers, and challengers. John Wiley \& Sons.

Pang, C., Wang, Q., Li, Y., \& Duan, G. (2019). Integrative capability, business model innovation and performance: Contingent effect of business strategy. European Journal of Innovation Management, 22(3), 541-561.

Pigliapoco, E., \& Bogliolo, A. (2011). A service-based Model for the Internet Value Chain. The Second International Conference on Access Networks, (c), 13-18.

Plate, J., \& Ismail. (2020). Industry Summit, Promoting Digital Indonesia.

Pratono, A.H. \& Mahmood, R. (2014). The moderating effect of environmental turbulence in the relationship between entrepreneurial management and firm performance. Universal Journal of Management 2(7), 285-292.

Rivera-Rodríguez, H.-A., Garcia-Merino, T., \& Santos-Alvarez, V. (2017). How to Thrive in Turbulent Business Environments: Case Colombia's Mobile Telephony Industry. Mediterranean Journal of Social Sciences, 8(3), $133-141$.

Sanjaya, I. (2015). Analisis Struktur Pasar Penyelenggara Jasa Akses Internet di Indonesia. Buletin Pos Dan Telekomunikasi, 12(4), 291.

Srivastava, A. K. (2013). Modeling strategic performance factors for effective strategy execution. International Journal of Productivity and Performance Management, 62(6), 554-582.

Statista. (2020). Indonesia: internet penetration rate 2023. https://www.statista.com/statistics/254460/internet-penetrationrate-in-indonesia/.

Statista Indonesia (2020). Indonesia: internet penetration rate 2023 (2020). Retrieved from https://www.statista.com/statistics/254460/internet-penetration-rate-in-indonesia/

Stigter, H. (2002). Co-operation as a response to a turbulent environment. Scales-paper N200222 Scientific Analysis of Business Policy and SMEs, EIM business and policy Research, pp.1-41.

Synnes, E.L. \& Welo, T. (2016). Enhancing Integrative Capabilities through Lean Product and Process Development. Procedia CIRP 54 : 221-226.

Teece, D. J. (2007). Explicating dynamic capabilities: the nature and micro foundations of (sustainable) enterprise performance. Strategic Management Journal, 28(13), 1319-1350.

Turula, L. \& Bajgoric (2018). Innovation, firm's performance, and environmental turbulence: is there a moderator or mediator? European Journal of Innovation Management, 22(1), 213-232.

Tsai, K. H., \& Yang, S. Y. (2014). The contingent value of firm innovativeness for business performance under environmental turbulence. International Entrepreneurship and Management Journal, 10(2), 343-366.

Volberda, H., \& Van Bruggen, G. (1997). Environmental turbulence: A look into its dimensionality.

Wheelen, T. L., David, H.J., Hoffman, A., Bamford, N., \& Charles, E. (2015). Strategic Management And Business Policy: Globalization, Innovation, and Sustainability, $14^{\text {th }}$ Edition, Global Edition. Pearson

Wijen, F., \& van Tulder, R. (2011). International regulatory turbulence: strategies for success. RSM Discovery-Management Knowledge, 2(4), 4-6.

Wong, Y. J., Lee, C. Y., \& Chang, S. C. (2017). CEO Overconfidence and Ambidextrous Innovation. Journal of Leadership and Organizational Studies, 24(3), 414-430.

Wyman, O. (2020). Covid-19 Telecom Operators Response.

Yu, J. (2012). Dimensions of Firm Integrative Capability from the Perspective of Systems Engineering. Systems Engineering Procedia, 4, 393-401.

Zott, C., Amit, R., \& Massa, L. (2011). The Business Model: Recent Developments and Future Research. 
(C) 2021 by the authors; licensee Growing Science, Canada. This is an open access article distributed under the terms and conditions of the Creative Commons Attribution (CCBY) license (http://creativecommons.org/licenses/by/4.0/). 